\title{
1. EU Cohesion Policy and European spatial governance: an introduction to territorial, economic and social challenges
}

\author{
Franziska Sielker, Daniel Rauhut and \\ Alois Humer
}

\section{INTRODUCTION}

Strengthening its economic, social and territorial cohesion is one of the main objectives of the European Union (EU). The EU dedicates a significant proportion of its activities and budget to reducing disparities across regions, with particular reference to rural areas, areas affected by industrial transition and regions which suffer from severe and permanent natural or demographic challenges.

Policymaking at the European level has increased considerably, in most cases without the transfer of the matching competence. Cohesion Policy operates largely through financial incentives or co-finance schemes, with cohesion goals pursued through any spatially relevant policy areas. This enlargement in themes, (sector) policy initiatives and areas of interest on the one hand, and the EU's increasingly multi-layered (cross-border) governance approach - facilitated by new governance tools such as macro-regions or the European Groupings of Territorial Cooperation - on the other hand, raises the need to discuss these different aspects in a single volume. Parallel to this expansion of EU decision-making and the emergence of new governance tools, several policy agenda issues, such as the role of urban areas, remain unresolved. Some questions fall between two chairs - for example, housing questions or the integration of spatial policy approaches; with other questions, the EU and the Member States claim discretion - for example, the migration challenge, single-market threats through internal border controls or, more recently, the management of health crises. 
EU Cohesion Policy has been accompanied by broader developments, such as increasing regional disparities and spatial disintegration; a development which is contradictory to its goals. Although these problems have been identified for some time, discussion remains relatively muted. The dominance of competitiveness and growth agendas diverts our attention towards more nuanced, heterogeneous perspectives and leaves us with many blind spots. There is, however, also a need to identify and review the combined effects of the numerous policies, diverse funding schemes and governance supports that affect Europe's spatial development today.

In this edited volume, we bring together planning and regional scientists who have worked on these aspects of European policies, with each adding a new perspective. The explicit spatial perspective enriches the thematic policy-oriented approach taken in the book, which is combined with a detailed critical assessment of the themes and questions that partly fall in-between the current policy set-ups. On purpose, the book offers no single view towards the policy processes that influence cohesion. This volume will not leave its readers with a peaceful conclusion, but rather offers a starting point for further and deeper discussion. We expect to 'ruffle some feathers' with this contribution, though hopefully in a positive sense. Ultimately, we call for combined, integrative rethinking on EU Cohesion Policy governance and contend that Cohesion Policy can play a renewed role in these times of frightening uncertainties about the future of the EU as a societal-political project.

\section{COHESION POLICY AND REGIONAL POLICY}

The terms 'Cohesion Policy' and 'Regional Policy' are widely, indeed almost interchangeably, used. Many perceive the term 'Cohesion Policy' to be the 'new name' for 'Regional Policy'. However, discrepancies remain in relation to the usage of Cohesion Policy as a concept as regards the technical terms 'Cohesion Policy' and 'Regional Policy'. In technical terms, 'Cohesion Policy' is the policy behind the hundreds of thousands of projects across Europe that receive funding from the European Regional Development Fund (ERDF), European Social Fund (ESF) and Cohesion Fund (CF; CEC, 2020a). The European Commission says that Regional Policy is delivered through the ERDF and the CF (CEC, 2020b). Taken together with the ESF, these are the delivery units of the Cohesion Policy. The European Structural and Investment Funds (ESIF), in addition, include the European Agricultural Fund for Rural Development (EAFRD) and the European Maritime and Fisheries Fund (EMFF), which are managed by DG (Directorate General) AGRI and DG MARE respectively. Notably, beyond these technical terms, the use of 'Cohesion Policy' is rather broad. The shift towards an increased and broader 
use of 'Cohesion Policy' is also reflected in the renaming of the Commissioner Post to Commissioner for Cohesion and Reforms.

The ERDF (established in 1975), considered as the delivery arm of traditional Regional Policy, targeted four key priorities in the funding period 2014-2020: (1) research and innovation, (2) information and communication technologies, (3) small and medium-sized enterprise (SME) competitiveness and (4) a low-carbon economy, highlighting the increasing focus on economic development in Regional Policy. In practice, this means that 80 per cent of ERDF funding in more developed regions, 60 per cent in transition regions and 50 per cent for less developed regions needs to go into two of these key priorities. A further seven objectives (climate change and risk prevention, environment and resource efficiency, transport and energy networks, employment and labour market, social inclusion, education and training and efficient public administration) illustrate the increasing role the ERDF has been given in co-financing sector policies. The thematic objectives will, in the funding period 2021-2027, be called policy objectives for Regional Development and the New Cohesion Policy. The five key objectives are as follows:

- a Smarter Europe, through innovation, digitisation, economic transformation and support to small and medium-sized businesses

- a Greener, carbon free Europe, implementing the Paris Agreement and investing in energy transition, renewables and the fight against climate change

- a more Connected Europe, with strategic transport and digital networks

- a more Social Europe, delivering on the European Pillar of Social Rights and supporting quality employment, education, skills, social inclusion and equal access to healthcare

- a Europe closer to citizens, by supporting locally-led development strategies and sustainable urban development across the EU. (CEC, 2020c; original emphasis)

Generally, Regional Policy encompasses the funds managed by DG REGIO, while Cohesion Policy encompasses those managed by DG REGIO and DG Employment, with the ESIF encompassing funds managed by DG REGIO, DG MARE, DG Employment and DG AGRI. The NextGenerationEU funds, the reaction of the EU to the Covid-19 crisis, has the Recovery and Resilience Facility as well as the Just Transition Fund at its heart. These will be delivered through a Recovery and Resilience Task Force within the European Commission's Secretariat-General.

Altogether, the above-mentioned funds aim to contribute to a balanced and harmonious development within Europe. The ESIF, and in particular its management through the various DGs, highlights an important understanding of Cohesion Policy; an aspect which gave us the impetus to develop the ideas within this book: No coherent, overarching, EU framework - with the overall goal of reducing spatial differences - for the spending of these funds currently 
exists. Rural policies, for example, are managed within DG AGRI and the ongoing process of the development of a rural agenda is largely driven by DG AGRI and the Commissioner for Democracy and Demography, with DG REGIO playing only a minor role. No policy coordination exists between the spending of the rural funds and the regional funds. As spatial scholars, however, we follow an understanding that the diversity of measures and policies relevant for spatial development does, in one way or another, influence cohesion. The absence of a coherent framework makes asking questions arising from these diverse approaches even more relevant.

In parallel with the technical terms, a broader concept of cohesion (policy) has been generated by the existence of cohesion as an overarching EU goal. The inclusion of economic, social and territorial cohesion as goals in the Lisbon Treaty suggests that all EU policies aim to support cohesion in the EU. Social and economic cohesion have been EU goals since the establishment of the ESF in 1957. These goals are also supported through a number of further funds, such as the Fund for European Aid to the Most Deprived (FEAD) or the Youth Employment Initiative (see Rauhut and Sielker, 2021).

The goal of territorial cohesion entered the text of the Lisbon Treaty to the surprise of many on the request of the outermost regions; specifically, those who considered themselves to be not favourably targeted by the social and economic cohesion goals. This gave rise to a broad debate over what territorial cohesion actually means. Cohesion, and territorial cohesion in particular, remains deliberately vague (Neufeld, 2017), offering a broad framework which allows for the encompassing of the full diversity of national visions. Further, by keeping the 'cohesion' goal, the use of funds can be amended to reflect changing political priorities and narratives.

\section{CHANGING NARRATIVES}

The EU has changed considerably since the ESF was established in 1957, and with it, the EU's Cohesion Policy (see, for example, Faludi, 2010). As McCann and Ortega-Argilés (2021) suggest, Cohesion Policy has adapted to evolving circumstances. The circumstances accompanying the development of Cohesion Policy and European spatial governance can thus be contextualised. We structure this alongside nine changing major development narratives:

\section{From a Regional Integrated Policy to an Economic Support Scheme}

The Lisbon Strategy, followed by the Barca Report with its emphasis on a place-based Regional Policy, led to a shift in policy from integrated Regional Policy to economic support scheme with, at the same time, the increasing sectorisation of European spatial policies taking place (Sielker, 2018a). Through 
the focus on innovation and research combined with thematic concentration, these funding schemes increasingly supported investments in the economy; for example, in SMEs. As a result, a shift from private to public project lead partners became perceptible. In practice, this means that the integrated perspective of regional development eroded as projects were not built as part of a bundle of measures related to urban and regional development. More affluent regions could not, for example, continue to fund cultural heritage through the ESIF.

The move away from this classical approach around local and spatial development towards an emphasis on economic policy was accompanied by less visibility for citizens, and potentially for the economy itself. The EU funds could, for example, be used as top-up financing for investments in SMEs for business renovation purposes or for the purchase of instruments and machines. Critical voices argued that this led to massive deadweight effects for developments that would have taken place in any case. As a result of these developments, combined with the Barca Report, a new focus on smart specialisation emerged (see McCann and Ortega-Argilés, 2021; Serbanica, 2021).

\section{A Weak Urban Focus}

Urban areas have become the growth poles of Europe's economy, with an increasing percentage of investments and Regional Policy spending targeting these areas (see Zimmermann and Atkinson, 2021). This is simply due to the location of existing economic activities. A specific urban focus first became noticeable with the urban community initiative launched in the funding period 1994-99, albeit with no more than 0.3 per cent of overall ERDF funding attached. In the following periods, the Member States preferred to follow a mainstreaming strategy. This means that the approach of the urban community initiative became relevant for all funds and that a certain amount of the funds could and should be used for urban projects. Over the course of time, however, the initial approach associated with urban integrated development diminished in importance.

When Commissioner Johannes Hahn took over, DG REGIO became the General Directorate for Regional and Urban Policy. Anecdotally illustrating his focus on urban development, in his opening speech addressing DG REGIO staff he highlighted the three priorities and then, to the surprise of many, added a fourth: 'urban development'. He aimed to rename his Commissioner post to add the urban dimension. However, the mandate of a Commissioner could not be changed, and as a result he remained the Commissioner for Regional Development and only the DG became the DG for Regional and Urban Policy. Funding-wise this did not change much. Nevertheless, urban matters did receive renewed attention in DG REGIO. A rough estimation, following some calculations on the European Open Data Portal, suggests that approximately 
one-quarter of the funds available go to urban matters with three-quarters going to rural regions. At the policy level, however, the last decade has seen an increase in policies targeting urban areas. The Urban Agenda which was adopted in 2016 represents the most recent push for an orientation of policies to urban developments. Its impact as yet remains to be seen, though the overall funding distribution and organisation in the funding period 2021-27 has not really changed. In sum, the urban approach in EU Cohesion and Regional policy remains unresolved (see Franz and Humer, 2021; Rauhut and Humer, 2020).

\section{EU Membership: A Diversification of Cultures and Demands}

With its various accession rounds, the EU, starting from the era of the European Coal and Steel Community, today comprises 27 Member States, down from 28 after the UK left in 2020. The largest accession rounds were the 2004/2007 Eastern Enlargements where 11 Member States joined. For Cohesion Policy, this increase implied numerous changes, one example being new demands on the spectrum of policies the EU was tackling.

An obvious change here is the importance now afforded to net-payers and net-receivers. The Eastern Enlargement in 2004 was not only the largest but is also broadly understood to have had the most wide-ranging impact. 'Catching up' became the predominant narrative. At the same time, these enlargements led to an influx of new administrative cultures and ways of doing things. The EU had, in a very short period of time, to embrace an even more multidisciplinary culture.

\section{EU Decision-Making Processes: Power Lies with the European Council}

The legal decision-making process requires the European Commission to draft a proposal for a regulation or a directive. The Commission can either draft a proposal based on its own initiative or as a reaction to having been tasked to do so by the European Parliament or European Council. The draft regulation will then be scrutinised in parallel by the European Council and the Parliament, resulting in suggestions for amended texts. The Committee of the Regions and the European Economic and Social Committee are also given the opportunity to comment on these drafts. These two documents, and comments received, will then be discussed in so-called 'trialogue' meetings. Here, the European Commission is invited to expand on the reasons for its previous draft and comment on the proposals by the Council and the Parliament. The trialogue's aim is to result in an agreed text. The two legislators, the European Parliament and the European Council, will then decide on the text (Nugent, 1989 [2006]; Sielker, 2018b). With the Lisbon Treaty the role of the European Parliament 
was considerably reinforced, providing a new, more supranational, narrative to the legal process, to the negotiations of the Multiannual Financial Framework (MFF) and, thus, also to the shape Cohesion Policy takes.

Over the last funding periods, the Parliament has been influential in strengthening overall goals such as those linked to climate change as well as linking cohesion funding to these goals where - for example, in discussions around the Resilience and Recovery Fund as well as the Just Transition Fund it has been instrumental in including rule of law stipulations and strengthening climate goals.

In terms of Cohesion and Regional policy, as well as European spatial governance tools, the dominance and the insistence of the European Council is of particular relevance. Due to the significant portion of the EU's budget that goes into Cohesion and Regional policy, this is a field that is negotiated in great detail in the MFF. As unanimity is required to secure a deal in the European Council, once it is reached the Member States are unlikely to untie the deal. The European Parliament is only required to consent to the proposal, which in practice amounts to an 'approve' or 'reject' position without the opportunity to make amendments. For the MFF 2021-27, the final position of the European Council was decided during the German presidency in the second half of 2020. Once the MFF is established, Cohesion and Regional policy fall under shared management, where the Member States have considerable influence on the spending of the budgets through their design of the (national and regional) Operational Programme (see Cotella and Dąbrowski, 2021). The implication here is that there is no coherent EU Cohesion Policy in the spending of the budget results with respect to its design and implementation. The dominant role of the European Council and the underlying territorial approach of the ESIF is central to understanding the opportunities for a more joined-up approach. Faludi (2016, p. 303) even concludes that 'the achievement of territorial cohesion in Europe is deeply problematic due to the territoriality of EU Member States'.

Regarding European spatial governance, new governance tools, such as European macro-regions, have been less contentious, while new European government tools such as the European Cross-Border Mechanism have proven to be contested, in particular by the European Council (Sielker, 2016, 2018b).

\section{Role of Personalities and Change of the 'Portfolio'}

Both Regional and Cohesion policy have been driven by personalities who believed in the cohesion goals. This is in particular by those in the Directorate for Urban and Regional Policy. While this continues to be the case, Regional Policy is increasingly used as a vehicle to support a broad set of goals now driven by different DGs. The general shift in term usage from Regional 
Policy to Cohesion Policy is manifested in the change from Corina Crețu as Commissioner for Regional Policy to Elisa Ferreira as the Commissioner for Cohesion and Reforms. From Hans von der Groeben to Elisa Ferreira, 15 Commissioners have headed the DG. Within the Brussels 'cloud', however, and despite the considerable amount of funding managed by DG REGIO, other portfolios are increasingly gaining in terms of political interest and visibility. One such example here being the increasing importance given to DG MOVE and DG CLIMA. As such, DG REGIO is now considered to be an administrative, less political DG organising the redistribution of money through the ERDF and CF.

\section{Increase of Topics and Policies}

A further circumstance shaping Cohesion and Regional policy is the emergence and growth of numerous policies at the EU level. The European Commission's website currently lists 291 policies (CEC, 2020b). Considering the spatially relevant policies, sector policies have continuously gained in importance at the EU level. The most important fields are agriculture, energy, environment and climate change, maritime affairs and fisheries, and transport. Examples of new spatially relevant policies include the Maritime Spatial Planning Directive (see Moodie et al., 2021), housing efforts (see Tosics and Tulumello, 2021) or migration (see Gruber and Németh, 2021).

These policies come with their own sets of objectives. The overall budget remains the same, which leads to earmarking and co-funding between the different funding streams. To give an example, projects can use ERDF funds to complement the project funding implemented through the Connecting Europe Facility. This example is illustrative of the support given to EU sector policies and broader EU policies by the cohesion funds.

\section{Disintegration, 'Integration Mark 2' and the 'Geographies of Discontent'}

The Western Hemisphere and its democratic political systems have over the last decade experienced the rise of the extreme right. The literature on 'geographies of discontent' (McCann, 2018) covering these debates has proliferated considerably over the last four years. In essence, it contends that citizens' feeling of 'being left behind' results in revenge at the ballot box in favour of populist parties (Rodríguez-Pose, 2018). Interregional inequalities exacerbated by the financial crisis pose a threat to the democratic institutional order (see McCann and Ortega-Argilés, 2021; Rauhut and Costa, 2021). The literature around the 'geographies of discontent' therefore addresses voting behaviours within countries. The rise of populist parties is a backdrop against which disintegration trends have arisen. Euroscepticism and anti-EU parties have gained 
popularity all over Europe, with Poland, Hungary and Italy being the most prominent examples.

With the UK leaving the EU, the EU has, for the first time in its history, experienced what it means to untie existing knots and to negotiate a new form of relationship. Evrard and Chilla (2021) note that the existing literature has failed to discuss or envision processes of disintegration or, as Faludi (2021) prefers to term it, 'integration mark 2', and that Euroscepticism is here to stay. Euroscepticism on the one hand, and increasing inequalities combined, fostered in part by the devastating results of ill-designed austerity policies and the impact of the financial crisis, clearly represent a challenging backdrop for Cohesion Policy.

Cohesion and Regional policy aspire to reduce disparities across the EU and bring Europe closer together. Yet, the question remains, why should the EU continue to invest in Cohesion Policy if, despite its efforts, Euroscepticism prevails? Rodríguez-Pose and Dijkstra (2020, p. 3) have addressed this question, concluding that 'EU investment in regional development has contributed to reduce the share of votes for all types of Eurosceptic parties'. They continue by stating that 'the connection between EU investment in regional development and a reduction in the Eurosceptic vote is highly contingent on the type of investment carried out in different regions across the EU and on their efficiency'.

The contemporary Covid-19 crisis already indicates that less affluent regions will disproportionally suffer from the impacts of the economic downturn, making Cohesion Policy an important recovery tool, in a period where the feeling of being 'left behind' in the 'geographies of discontent' may actually grow in the short to medium term.

\section{Global Challenges}

Global developments have always impacted EU development. The ChineseUS trade war, which proliferated during the Trump presidency hit European regions that were net-exporters hardest. Looking through a spatial lens, the increase of international foreign direct investments in critical infrastructure is one major aspect of this. Take, for example, Chinese investments through the Belt and Road Initiative, launched in 2013 (Maçães, 2018; Sielker and Kaufmann, 2020): For the EU Danube Region countries, Chinese infrastructure funding comes with little administrative burden, in contrast to funding from the Connecting Europe Facility in the framework of the Trans-European Transport Network (TEN-T) corridors. The pursuit of a new north-south corridor through Eastern Europe is robustly supported by China. Europe has increasingly been subject to a narrative posing an East-West divide between political cultures, particularly in respect of expectations of EU membership 
and economic strength. The increasing influence of Chinese investments and the $17+1$ initiative with Central and Eastern European states provided a new framework in which EU Member States can find an alternative in terms of project implementation. While this development has not been nearly as straightforward as initially assumed, or feared by others, looking at Cohesion Policy and its goals, one needs to consider other parallel and at times competing developments played out in negotiations. Another example here is the challenges posed by uneven labour migration and integration issues (see Gruber and Németh, 2021).

\section{Regional Policy, ETC and New Spaces}

An often cited map by AEBR (2011) shows the countless spaces of cooperation in Europe. These numerous areas of cooperation have increased considerably since the start of grass-roots developments in the 1950s through the Euro-regions. Since the introduction of the transnational EU programmes, the general organisation of the funds remains the same, though Interreg has been renamed ETC (European Territorial Cooperation). Some smaller investment opportunities include the integrated territorial investments (ITI) or Community-Led Development (CLLD). These do not, however, feature alongside new funds, but instead build on the existing five funding streams of Cohesion Policy. This trend, that new spatial configurations and cooperation instances are accompanied by a paradigm of no new funds and no new institutions, has already been indicated by the development of European macro-regions since 2009 (Gänzle et al., 2019; Sielker, 2016). Notably, these new initiatives find themselves in the sphere of governance support. In a similar vein, the European Groupings of Territorial Cooperation and the proposed European Cross-Border Mechanism are indicative of this new trend (Sielker, 2016). Academia has now started to conceptualise these new spatial paradigms, debating the functional soft spaces that develop as a result (see Allmendinger et al. 2014, Purkarthofer and Schmitt, 2021). At the same time, these spaces offer opportunities for the coordination of sector policies (Sielker, 2018a), while prefiguring a trend for a future European spatial governance.

While these developments point to a continuous dynamic of new cooperation areas, it should nevertheless be noted that the budgetary consequences are very limited and that many of these developments have been Member State-driven. Recently, major new initiatives from the Commission in the sphere of Regional Policy have, however, been quite rare. While this may be criticised, one can also argue that it is a major achievement that Regional Policy still actually exists. 


\section{COHESION POLICY AND CONTEMPORARY POLITICAL DEBATES AT THE EU LEVEL: A EUROPEAN FOCUS?}

The cohesion goal provides a central narrative to EU policies, particularly since the inclusion of the territorial cohesion goal into the Lisbon Treaty. Spatial scholars immediately started debating its meaning. Simultaneously, significant portions of EU funding are dedicated to achieving the EU cohesion goal by various means. Yet, following the political focus and debate in Brussels, territorial cohesion is not a priority. Policies that we consider are contributing to territorial cohesion and spatially relevant, such as the Green Deal or the new Recovery and Resilience Facility, do not reference the cohesion goal or take the cohesion goal as a point of orientation.

This book will be published during the Von der Leyen Commission period. On her appointment, she outlined six headline ambitions for Europe: 'A stronger Europe in the world', 'A European Green Deal', 'A Europe fit for the digital age', 'An economy that works for people', 'A new push for European democracy', and 'Promoting the European way of life'. With these goals, the President pledged to lead a 'geopolitical' and more sustainable, diverse, climate-friendly, digital and democratic Commission. Following the economic turmoil precipitated by the Covid-19 pandemic, these priorities have been augmented by the NextGenerationEU goal to support EU countries and their economies in the current crisis.

These political priorities are all in one way or another connected to the cohesion goal. Our point is that the 'cohesion goal', despite its central position in the Lisbon Treaty, rarely finds its way into the phrasing or design of these contemporary priorities, nor, indeed, of former priorities. For instance, the European Green Deal mentions the term 'cohesion' twice; first, (CEC, 2019 , p. 15) to earmark money to 'deliver on climate-related cohesion policy objectives in their territories and region', and second, to note that the Climate Pact will help to strengthen the 'urban dimension of cohesion policy', and that 'the proposed European Urban Initiative will provide assistance to cities to help them make the best use of opportunities to develop sustainable urban development strategies' $(2019$, p. 23). Notably, the term 'cohesion' is here presented as a rather contextual reference, with both climate and urban policies remaining largely in the Member States' hands. The reference to cohesion highlights that the role attributed to Cohesion Policy is to support implementation of the Paris Agreement and the Urban Agenda for the EU. Similarly, the Just Transition Fund will

be established within the framework of cohesion policy which is the main EU policy instrument to reduce regional disparities and to address structural change in 
Europe's regions - sharing cohesion policy's objectives in the specific context of the transition towards climate neutrality. (CEC, 2020d, p. 3)

The regulation further outlines that up to 20 per cent of its initial ERDF and ESF+ allocation (calculated per fund) can be transferred to the Just Transition Fund.

Why do we highlight this? The Cohesion Policy is generally considered to be a tool for the redistribution of money, where considerable amounts of the funds allocated to Cohesion Policy are earmarked or allowed to complement other funds and support the implementation of contemporary policy priorities. These goals certainly contribute to the cohesion goal, albeit indirectly. Moreover, these developments do not indicate that the cohesion goal has itself become less important. What is obvious, however, is that the undefined and deliberately broad conceptualisation of cohesion provides a framework which allows the Commission and, by extension, the Member States to reallocate funds and pursue cohesion goals by lining up with other funds. This is also one of the reasons why Cohesion and Regional policy, with their attached funds, remain among the most contested topics in the MFF debates.

These are the developments that prompted us to take a closer look at a number of 'unsettled questions' within the context of EU Cohesion Policy and European spatial governance. Over time, the EU's structural funds and in particular the ERDF, ESF and CF have become sources of funding complementing a broad set of policies. This extension of topics, policies and narratives has led to the development of a complex set of policies contributing to cohesion. This also leads to the setting of numerous goals and priorities in their own right, which do not in fact follow a coherent approach; hence the emergence of the above-mentioned 'unsettled questions', challenges or topics.

\section{THE STRUCTURE OF THIS BOOK}

In this book we focus on the three dimensions of EU Cohesion Policy, each discussed in a separate part. To us, the topic of territorial cohesion is closely related to wider aspects of territorial governance and spatial planning in the EU. Therefore, the first part discusses challenges in the field of territorial governance. The second addresses the economic dimension of Cohesion Policy, raising key questions around inequality, while the third focuses on social and well-being aspects. One particular aspect of our edited volume is that we place significant emphasis on discursively interrelating the chapters in three parts; each is preceded by a guiding, targeted introduction and concluded by an independent, synergetic commentary that challenges and re-values the regular chapters. 
The theme of territorial governance focuses on the territorial dimension of EU Cohesion Policy. To attain the objective of balanced and sustainable development, many researchers have discussed the need for an integrated approach implying better coordination between sectoral policies at each level, from the local to the European. In the aftermath of adding the territorial dimension to Cohesion Policy, demands arise from different types of territories to be supported in their development. The shift from cohesion to competitiveness is a widely debated aspect among scholars while the issues of functional regions, 'soft spaces' and the extent to which territorial cohesion is a policy tool for Europeanisation, or even 'Europeanisation', are also debated. Other areas, such as maritime planning, are new and partly unexplored in terms of territorial cohesion.

The theme of urban and regional inequalities addresses the economic dimension of EU Cohesion Policy. Issues related to economic growth, competitiveness and how to achieve a (relatively) balanced regional development have, over time, been core issues for the EU and its Member States. How to bridge the economic gap between old and new Member States has been and remains a central element of the long-term approach to EU Cohesion Policy. One aspect to consider here is the never-ending debate on the importance of polycentrism (Meijers and Sandberg, 2021). The role of the analytical scale used for analysing inequalities is also addressed here. Other areas discussed in this theme relate to smart specialisation and how this is related to a reduction in regional inequalities and how the EU Cohesion Policy combats peripherialisation and hence reduces regional inequalities (Nagy and Benedek, 2021; Védrine and Le Gallo, 2021). Lastly, the issue of how EU Cohesion Policy affects interregional as well as intraregional inequalities is discussed.

The theme of social aspects and well-being focuses on the social dimension in EU Cohesion Policy. Despite the EU's increasing ambitions in the social policy area, the number of displayed successes in its priority areas on social exclusion, poverty and improved housing access remain limited. The key question here is that social policy remains largely at the discretion of the Member States. The EU continues, however, to provide strategic orientation in social policy areas such as employment/unemployment, lifelong learning, working time, gender balance and the rights of ethnic minorities, among others. However, such initiatives are not related to Cohesion Policy. The contributions to this part highlight how disputes over discretion between the European Commission and the Member States on social policy issues generate an inertia for policy ambitions and policy implementation (Marques da Costa, 2021).

This introduction precedes a contribution by McCann and Ortega-Argilés (2021) on the history of EU Cohesion Policy and a reflection on future development needs. We, as editors, later provide a discussion and summary of the unresolved questions that emerge from these multiple debates alongside the 
three challenges of disintegration, discontent and discretion. The Afterword by Kunzmann (2021) raises a meta-critical voice towards an evermore flourishing publication culture asking us to not lose sight of political realities.

\section{REFERENCES}

AEBR (2011), Cooperation in Europe, accessed at https://i1.wp.com/www.aebr.eu/wp -content/uploads/2020/08/AEBRmap2011 finalversion.jpg? $\mathrm{w}=924 \&$ ssl=1.

Allmendinger, P., Chilla, T., and Sielker, F. (2014), 'Europeanizing territoriality: towards soft spaces?', Environment and Planning A, 46 (11), 2703-2717.

Barca, F. (2009), An Agenda for a Reformed Cohesion Policy: A Place-Based Approach to Meeting European Union Challenges and Expectations, accessed at www.europarl.europa.eu/meetdocs/2009_2014/documents/regi/dv/barca_report_ barca_report_en.pdf.

CEC (2019), Communication from the Commission to the European Parliament, the European Council, the Council, the European Economic and Social Committee and the Committee of The Regions - the European Green Deal, accessed at https://ec .europa.eu/info/sites/info/files/european-green-deal-communication_en.pdf.

CEC (2020a), Regional Policy, accessed at https://ec.europa.eu/regional_policy/en/ faq/\#1.

CEC (2020b), The EU's Main Investment Policy, accessed at https://ec.europa.eu/ regional_policy/en/policy/what/investment-policy/.

CEC (2020c), New Cohesion Policy, accessed at https://ec.europa.eu/regional_policy/ en/2021 2027/.

CEC (2020d), Regulation of the European Parliament and of the Council, establishing the Just Transition Fund, accessed at https://ec.europa.eu/info/law/better-regulation/ have-your-say/initiatives/12113-European-Green-Deal-Just-Transition-Fund.

Cotella, G., and Dąbrowski, M. (2021), 'Cohesion Policy as a driver of Europeanisation: a comparative analysis', in Rauhut, D., Sielker, F., and Humer, A. (eds) EU Cohesion Policy and Spatial Governance: Territorial, Economic and Social Challenges. Cheltenham, UK and Northampton, MA, USA: Edward Elgar Publishing.

Evrard, E., and Chilla, T. (2021), 'European (dis)integration: implications for the EUropean Cohesion Policy', in Rauhut, D., Sielker, F., and Humer, A. (eds) EU Cohesion Policy and Spatial Governance: Territorial, Economic and Social Challenges. Cheltenham, UK and Northampton, MA, USA: Edward Elgar Publishing.

Faludi, A. (2010), Cohesion, Coherence, Cooperation: European Spatial Planning Coming of Age? London: Routledge.

Faludi, A. (2016), 'EU territorial cohesion: a contradiction in terms (comment)', Planning Theory \& Practice, 17 (2), 302-13.

Faludi, A. (2021), 'Complex EU cohesion and "Integration Mark 2"', in Rauhut, D., Sielker, F., and Humer, A. (eds) EU Cohesion Policy and Spatial Governance: Territorial, Economic and Social Challenges. Cheltenham, UK and Northampton, MA, USA: Edward Elgar Publishing.

Franz, Y., and Humer, A. (2021), 'EU Cohesion Policy: towards grounded cities and regions', in Rauhut, D., Sielker, F., and Humer, A. (eds) EU Cohesion Policy and Spatial Governance: Territorial, Economic and Social Challenges. Cheltenham, UK and Northampton, MA, USA: Edward Elgar Publishing. 
Gänzle, S., Stead, D., Sielker, F., and Chilla, T. (2019), 'Macro-regional strategies, cohesion policy and regional cooperation in the European Union: towards a research agenda', Political Studies Review, 17 (2), 161-74.

Gruber, E., and Németh, Á. (2021), 'Mobility in the Danube region: the role of transnational cooperation in addressing challenges of migration', in Rauhut, D., Sielker, F., and Humer, A. (eds) EU Cohesion Policy and Spatial Governance: Territorial, Economic and Social Challenges. Cheltenham, UK and Northampton, MA, USA: Edward Elgar Publishing.

Kunzmann, K.R. (2021), 'Territorial cohesion: a never-ending academic challenge?', in Rauhut, D., Sielker, F., and Humer, A. (eds) EU Cohesion Policy and Spatial Governance: Territorial, Economic and Social Challenges. Cheltenham, UK and Northampton, MA, USA: Edward Elgar Publishing.

Maçães, B. (2018), Belt and Road: A Chinese World Order. London: Hurst.

Marques da Costa, E. (2021), 'Social issues and wellbeing in the EU - challenges for Cohesion Policy', in Rauhut, D., Sielker, F., and Humer, A. (eds) EU Cohesion Policy and Spatial Governance: Territorial, Economic and Social Challenges. Cheltenham, UK and Northampton, MA, USA: Edward Elgar Publishing.

McCann, P. (2018), 'The trade, geography and regional implications of Brexit', Papers in Regional Science, 97 (1), 3-8.

McCann, P., and Ortega-Argilés, R. (2021), 'EU Cohesion Policy: the past, the present and the future', in Rauhut, D., Sielker, F., and Humer, A. (eds) EU Cohesion Policy and Spatial Governance: Territorial, Economic and Social Challenges. Cheltenham, UK and Northampton, MA, USA: Edward Elgar Publishing.

Meijers, E., and Sandberg, K. (2021), 'Territorial cohesion, polycentrism and regional disparities: revisiting an unsolved debate', in Rauhut, D., Sielker, F., and Humer, A. (eds) EU Cohesion Policy and Spatial Governance: Territorial, Economic and Social Challenges. Cheltenham, UK and Northampton, MA, USA: Edward Elgar Publishing.

Moodie, J., Sielker, F., and Goldsborough, D. (2021), 'Territorial cohesion and the sea: experiences from European maritime spatial planning', in Rauhut, D., Sielker, F., and Humer, A. (eds) EU Cohesion Policy and Spatial Governance: Territorial, Economic and Social Challenges. Cheltenham, UK and Northampton, MA, USA: Edward Elgar Publishing.

Nagy, J.A., and Benedek, J. (2021), 'Can the EU Cohesion Policy fight peripheralization?', in Rauhut, D., Sielker, F., and Humer, A. (eds) EU Cohesion Policy and Spatial Governance: Territorial, Economic and Social Challenges. Cheltenham, UK and Northampton, MA, USA: Edward Elgar Publishing.

Neufeld, M. (2017), 'Eine Frage des Maßstabs? Zum Verhältnis von Kohäsion und Polarisierung in Europa', Europa Regional, 23.2015 (4), 15-29.

Nugent, N. (1989), The Government and Politics of the European Union, 6th edition (2006). Basingstoke and New York: Palgrave Macmillan.

Purkarthofer, E., and Schmitt, P. (2021), 'Spatial framing within EU Regional Policy and spatial planning: towards functional and soft spaces, yet on different paths', in Rauhut, D., Sielker, F., and Humer, A. (eds) EU Cohesion Policy and Spatial Governance: Territorial, Economic and Social Challenges. Cheltenham, UK and Northampton, MA, USA: Edward Elgar Publishing.

Rauhut, D., and Costa, N. (2021), 'What regions benefit from the post-2009 crisis Cohesion Policy? Evidence from a Territorial Cohesion Development Index', in Rauhut, D., Sielker, F., and Humer, A. (eds) EU Cohesion Policy and Spatial 
Governance: Territorial, Economic and Social Challenges. Cheltenham, UK and Northampton, MA, USA: Edward Elgar Publishing.

Rauhut, D., and Humer, A. (2020) 'EU and spatial economic growth: trajectories in economic thought', European Planning Studies, 28 (11), 2116-33.

Rauhut, D., and Sielker, F. (2021), 'Social aspects in the EU's Cohesion Policy: an introduction', in Rauhut, D., Sielker, F., and Humer, A. (eds) EU Cohesion Policy and Spatial Governance: Territorial, Economic and Social Challenges. Cheltenham, UK and Northampton, MA, USA: Edward Elgar Publishing.

Rodríguez-Pose, A. (2018) 'The revenge of the places that don't matter (and what to do about it)', Cambridge Journal of Regions, Economy and Society, 11(1), 189-209.

Rodríguez-Pose, A., and L. Dijkstra (2020), 'Does Cohesion Policy reduce EU discontent and Euroscepticism?', Regional Studies, accessed at https://doi.org/10.1080/ 00343404.2020 .1826040 .

Serbanica, C. (2021), 'Smart specialization, peripheries and the EU Cohesion Policy', in Rauhut, D., Sielker, F., and Humer, A. (eds) EU Cohesion Policy and Spatial Governance: Territorial, Economic and Social Challenges. Cheltenham, UK and Northampton, MA, USA: Edward Elgar Publishing.

Sielker, F. (2016), 'A stakeholder-based EU territorial cooperation: the example of European macro-regions', European Planning Studies, 24 (11), 1995 - 2013.

Sielker, F. (2018a), 'European spatial governance - towards a sectoralisation of spatial planning?', Journal of Property, Planning and Environmental Law, 10 (2), 126-39.

Sielker, F. (2018b), 'The European Commission's Proposal for a Cross-border Mechanism (ECBM): potential implications and perspectives', Journal of Property, Planning and Environmental Law, 10 (3), 219-239.

Sielker, F., and E. Kaufmann (2020), 'The influence of the Belt and Road Initiative in Europe', Regional Studies, Regional Science, 7 (1), 288-91.

Tosics, I., and Tulumello, S. (2021), 'Between markets and social rights: the EU housing policies', in Rauhut, D., Sielker, F., and Humer, A. (eds) EU Cohesion Policy and Spatial Governance: Territorial, Economic and Social Challenges. Cheltenham, UK and Northampton, MA, USA: Edward Elgar Publishing.

Védrine, L., and Le Gallo, J. (2021), 'Does Cohesion Policy affect territorial inequalities and regional development?', in Rauhut, D., Sielker, F. and Humer, A. (eds) EU Cohesion Policy and Spatial Governance: Territorial, Economic and Social Challenges. Cheltenham, UK and Northampton, MA, USA: Edward Elgar Publishing.

Zimmermann, K., and Atkinson, R. (2021), 'Urban policy in European Cohesion Policy', in Rauhut, D., Sielker, F., and Humer, A. (eds) EU Cohesion Policy and Spatial Governance: Territorial, Economic and Social Challenges. Cheltenham, UK and Northampton, MA, USA: Edward Elgar Publishing. 